\title{
Hanseatic fish trade in the North Atlantic: evidence of fish remains from Hanse cities in Germany
}

\author{
HANS CHRISTIAN KÜCHELMANN
}

Küchelmann, H. C. 2019. Hanseatic fish trade in the North Atlantic: evidence of fish remains from Hanse cities in Germany. AmS-Skrifter 27, 75-92, Stavanger, ISSN 0800-0816, ISBN 978-82-7760-183-0.

\begin{abstract}
This paper reviews the evidence for the Hanseatic fish trade in the North Atlantic from the perspective of the consumer sites: the Hanse cities in Germany. Stockfish, the most important good in the North Atlantic trade, are discussed from an archaeozoological perspective. The evidence from Hanse cities accumulated thus far is presented and evaluated. The amount of fish remains analysed from Hanse cities in Germany is still very low, which precludes in-depth research and wider conclusions. Nevertheless, overall patterns appear that are generally consistent with the assumptions of patterns for imported stockfish: high frequencies of Gadidae among the fish remains of coastal Hanse cities, overrepresentation of postcranial skeletal elements, prevailing remains of large size classes, and isotopic data supporting the hypothesis.
\end{abstract}

Hans Christian Küchelmann, Knochenarbeit, Speicherhof 4, D-28217 BREMEN, GERMANY.

E-mail: kuechelmann@dsm.museum,info@knochenarbeit.de

Keywords: Gadidae, stockfish, Hanse, North Atlantic trade, late Middle Ages, early modern period

When looking at the Hanseatic trade in the North Atlantic from an archaeozoological perspective, the focus is generally fish (Fig. 1a), which predominantly comprise dried stockfish. ${ }^{1}$ There are other trade goods from Nordic countries that can be detected with archaeozoological methods, like walrus or narwhal ivory, bear skins (Fig. 1b), falcons (Fig. 1c), and whale bone (Fig. 1d), but these are rare or luxury goods compared to the bulk good stockfish. One might say that stockfish were one of the economic backbones of the Hanse. Despite the huge amounts of stockfish imported by Hanseatic merchants, the present state of research on fish bone assemblages from Hanse cities in Germany is far from satisfactory.

\section{Methodological issues}

To make the conclusions and interpretations about the archaeozoological data understandable for scholars who are not familiar with biological and archaeozoological methods, it is necessary to outline some methodological key issues. Major factors that deter- mine whether or not organic material will be preserved are taphonomic agents, which are biotic and abiotic factors that affect any dead body in different ways and degrees. In general, all organic matter is subject to biological degradation, and a vast amount of animal bodies do not survive past death for more than a couple of years. But some environmental conditions are less favourable for biodegradation, and some biological tissues can withstand attacks from biodegrading agents longer than others, resulting in the eventual preservation of animal remains under special circumstances, sometimes over very long periods of time. One example is tissues rich in calcium carbonate, such as bones and shells. ${ }^{2}$

The majority of fish bones are unfortunately small and delicate and are thus less preservable compared to the bones of mammals and larger birds. This means that in poor preservation conditions, such as in aerobic substrates like sandy soils, fish bones will be among the first to vanish. But there are exceptions: large fish like sturgeon (Acipenser sp.) or tuna (Thunnus sp.) have large bones, and even adult cod (Gadus morhua) or 

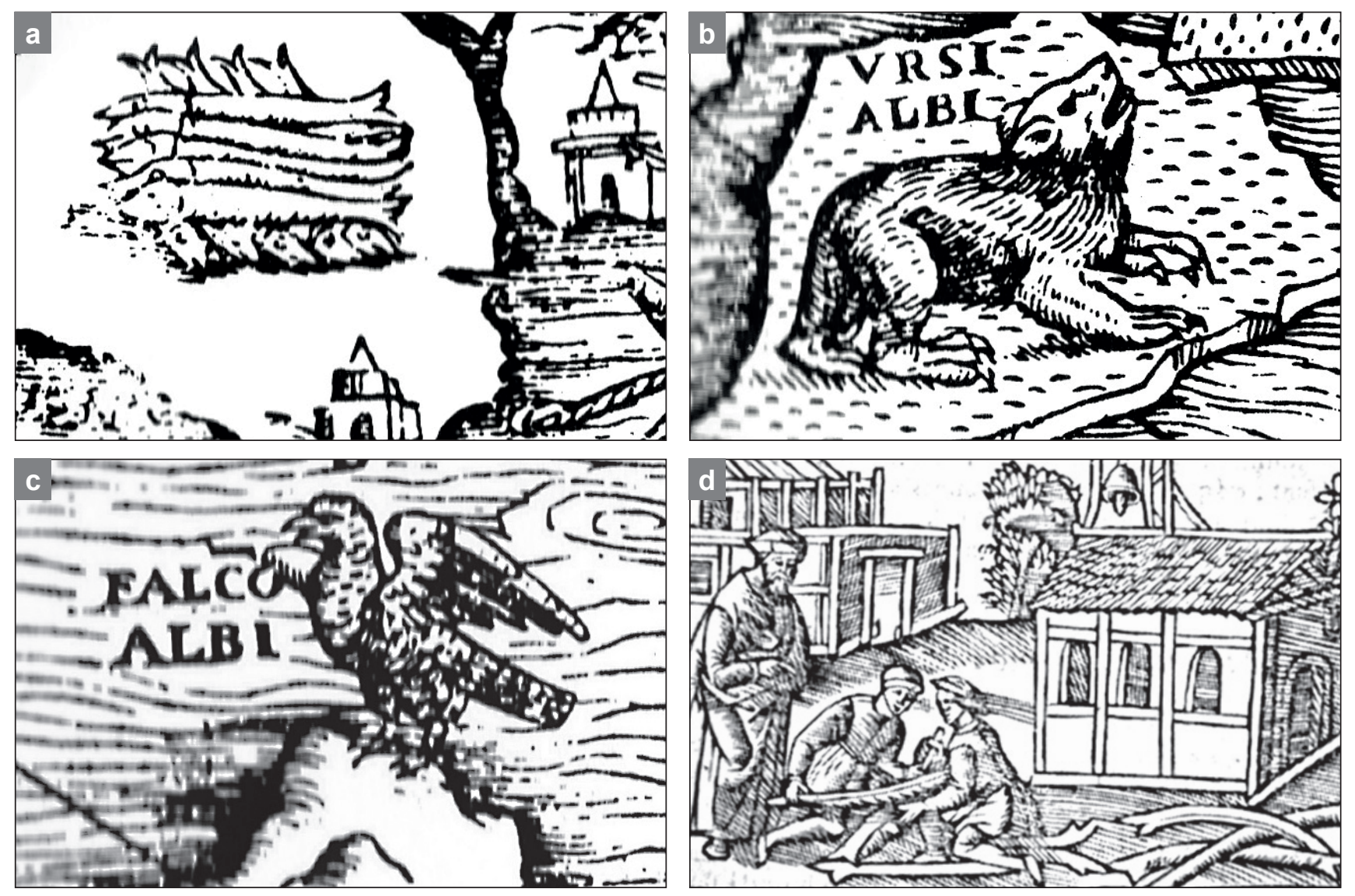

Fig. 1. Trade goods from Iceland related to archaeozoology; a) staple fish; b) polar bear skin (Ursus arctos); c) gyrfalcon (Falco rusticolus); d) whale bones used as logs (a-c) from Olaus Magnus, Carta Marina (1539) on Iceland, d) from Olaus Magnus. Die Wunder des Nordens (book 21)).

pike (Esox lucius) have at least some stout bones in the same size class as bones of medium-sized mammals or large birds. Consequently, these larger fish bones have a similar chance of surviving, provided that the preservation conditions are good. Much more important are the excavation methods, as methodical tests have shown. ${ }^{3}$ In hand-collected samples, the majority of the fish bones are usually overlooked due to their small size. In contrast, large amounts of fish bones, even from small species, can sometimes be recovered and identified from sieved samples. ${ }^{4}$

If fish remains happen to survive the ravages of time and the neglect of excavators, they may end up in archaeozoological labs for further analysis. Like all vertebrate animals, fish share basic physical structures, including regularly patterned homologous skeletal elements, but they display morphological differences between species. Therefore, it is possible to identify fish species bone by bone with the help of reference collections (Fig. 2) and published identification criteria - to the species level in some cases and at least to the family level in most cases. ${ }^{5}$ Complete bones can be measured using defined anatomical distances, ${ }^{6}$ which enable size estimations of individuals (Figs 3 and 4). After collecting primary data, various questions about an assemblage can be addressed, such as:

- Which species occur frequently, which are evident but rare, and which are missing?

- Which parts of the fishes are represented, and which are missing or underrepresented?

- Is the skeletal element representation in accordance with the anatomical frequencies of the elements?

- What is the taphonomical history of the assemblage?

- Are we dealing with production or consumption refuse or maybe even something else?

- Are patterns of standardised processing procedures visible? ${ }^{7}$

- Are there differences in spatial or diachronic distribution within the site?

Site-specific qualities can subsequently be used for inter-site comparisons using geographical, chronological, cultural, or social parameters in the search for differences and analogies. Beyond morphology and 


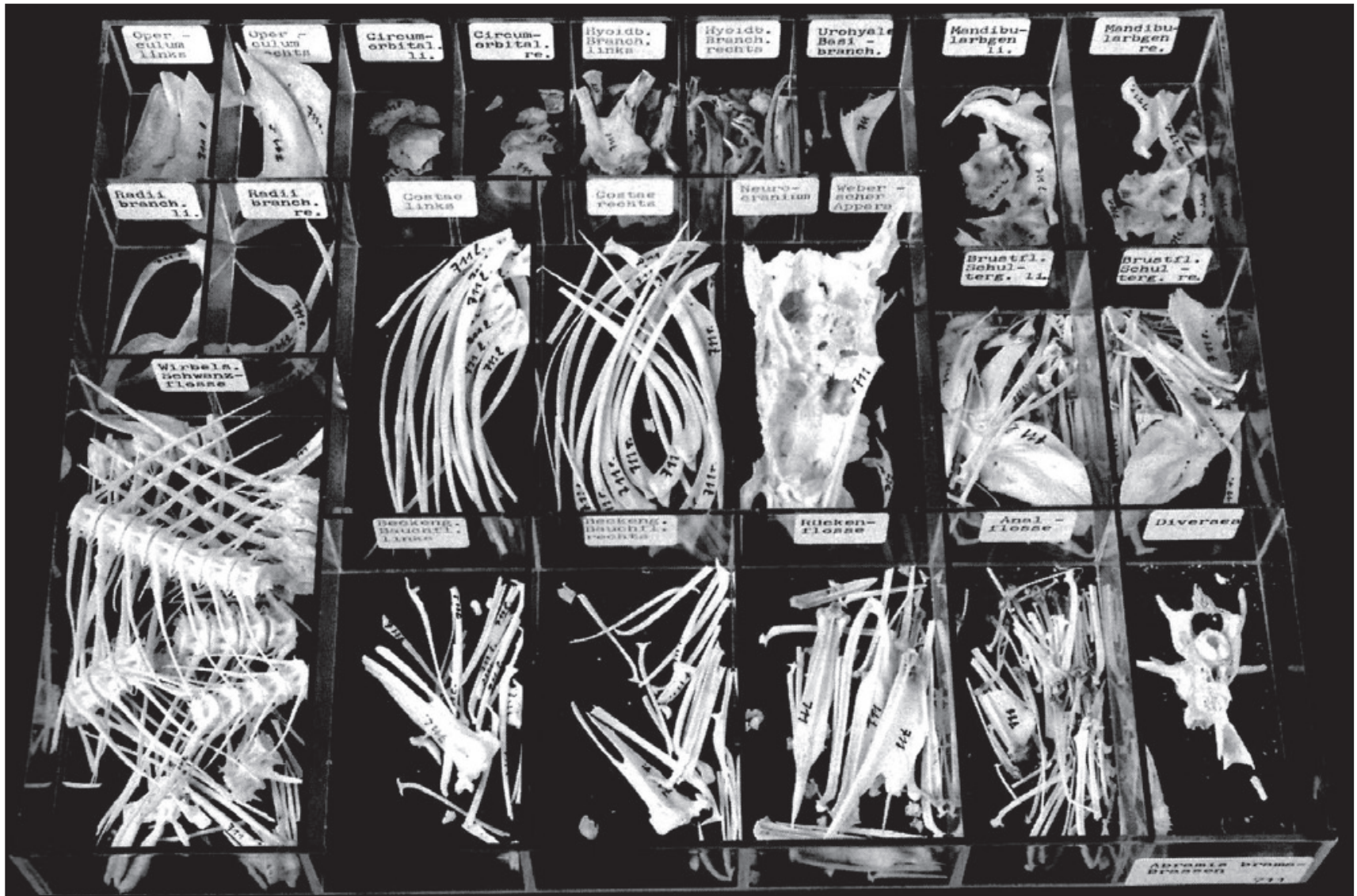

Fig. 2. Fish bone reference collection at the Archäologisch-Zoologische Arbeitsgruppe Schleswig (AZA) (from Heinrich et al. 1991, 17, fig. 13).

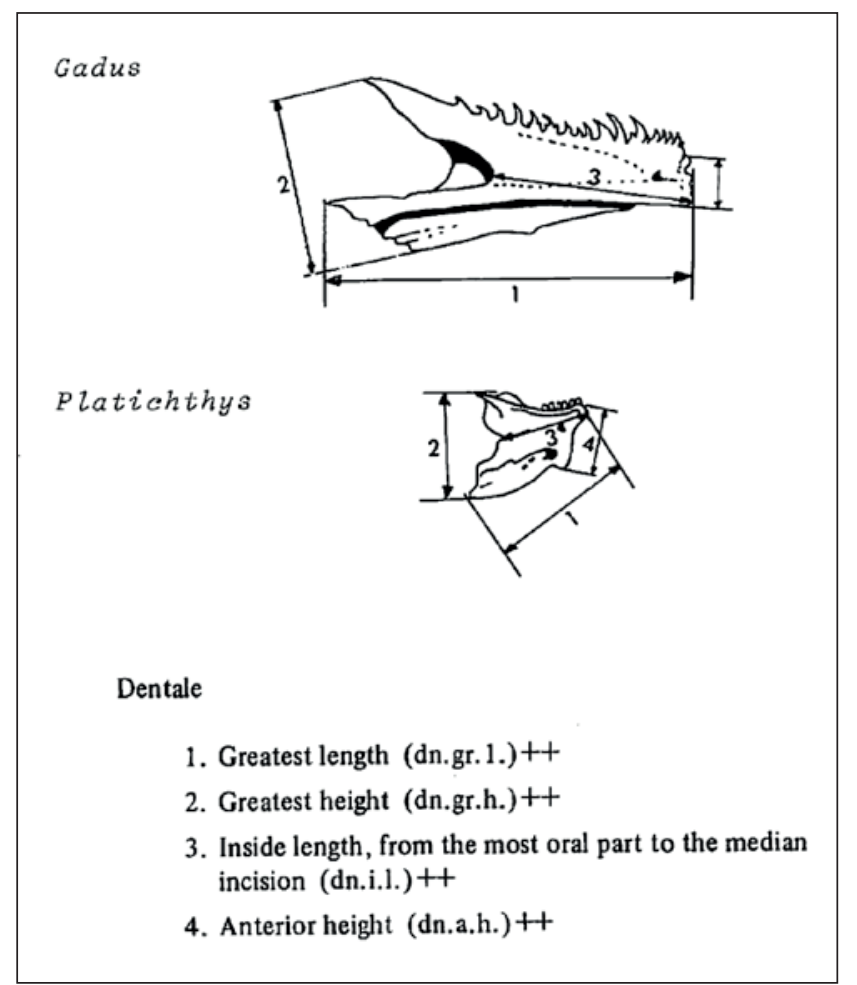

Fig. 3. Example of measurement distances on the dentale (from Morales and Rosenlund 1979, 22). osteometry, the identified bones can be sampled for biomolecular studies, such as stable isotope and aDNA analyses, thus revealing insights into the provenance of fish, population dynamics, etc.

\section{Stockfish seen from an archaeozoological perspective}

Before proceeding deeper into the details of fish remains found in Hanse cities, we must look at the production of stockfish from an archaeozoological perspective. Some premises must first be taken into account. Since the environmental conditions for cereal cultivation are limited in the North Atlantic region, people applied a mixed economy of stock breeding and exploitation of marine resources for subsistence. Fish appear in large numbers in this region, which has a low population density, thus providing the possibility of producing a surplus. Favourable environmental conditions (drought, cold wind) allow fish preserved through drying to be stored for future consumption. Finally, the advent of the Hanseatic trade system in Bergen resulted in major changes of the social-system 
Fig. 4. Example for size estimations of fish from Bremen, site 201-Altstadt, market place. Box $=$ distance 25th-75th quartile with median value, whiskers $=$ distance 10th-90th percentile, circle and stars = outliers (from Galik and Küchelmann 2008, 218, fig. 4).

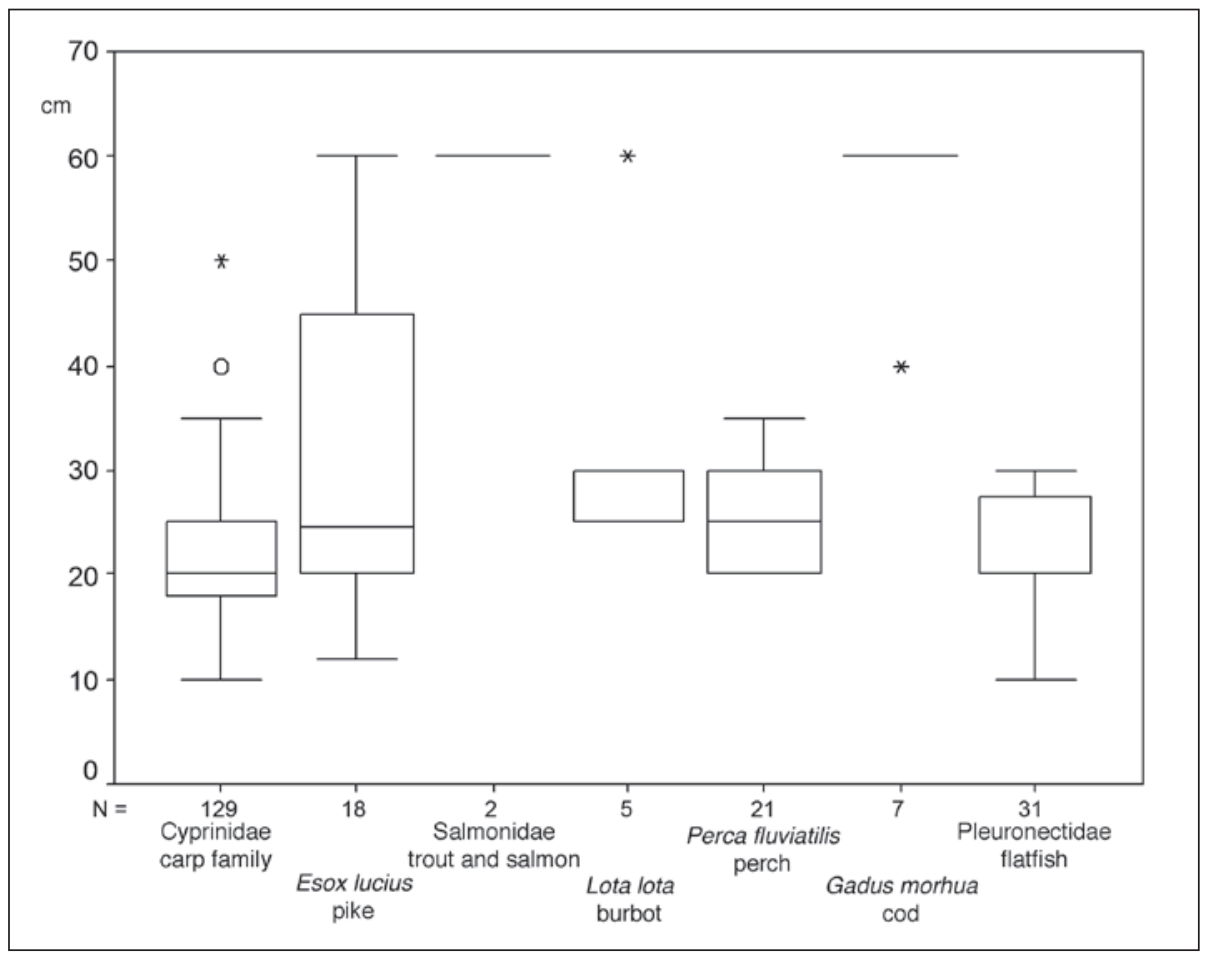

and life situations of the fishermen in the North Atlantic. ${ }^{8}$ Sophia Perdikaris summarized this development conclusively for the Lofoten: 'Sometime before ca. 1100 AD, Vågan developed into a major entrepot for winter fishing and large-scale fish processing for market. By the $14^{\text {th }}$ century, royal and church patronage of the developing cod fisheries and the influence of the growing Hanseatic outpost at Bergen played a major role in this transformation. By late medieval times, the Lofoten fisheries provided a significant portion of the fish catch of Western Europe, and a comparative organizational model for commercialization of subsistence fishing in the Shetland, north Britain and (after 1500) the New World. By 1500, the once independent fisher-farmers of the Lofoten and Vesterålen were caught up in debt-driven intensive winter fisheries and tied to economic fluctuations in markets thousands of miles away. ${ }^{9}$

While this straightforward argument is certainly true, it may be only part of the truth. Long before the existence of the Hanse, the inhabitants of the Lofoten were seeking trade relations with neighbouring peoples like the Sami. ${ }^{10}$ Furthermore, the relations between fishermen (North sailors, kopgenaten) and Hanse merchants were bilateral, at least up to certain limits, as Skivenes was able to document in sources from the Bergen archive. ${ }^{11}$ According to the contracts with fishermen, merchants were obligated to provide their partners in north Norway with essentials, even if few or no fish could be delivered due to adverse circumstances.
The transformation to a market-driven economy led to the mass production of stockfish, which is inevitably connected to the standardization of processing methods, quality, and size of the fish traded, and most likely to their taste (although this can no longer be detected from archaeozoological fish bones).

\section{Processing methods}

Different types of stockfish with different processing methods and a variety of qualities were distinguished by producers and tradesmen, which result in different potentials for archaeological recovery. According to archival sources, Hanseatic merchants distinguished different types of Atlantic cod (Germ. Dorsch, Kabeljau; lobben; Gadus morhua), particularly 'Rundfisch' (Rundvisch, rundfisk), 'Rotscher' (from Norw. råskjær), salted cod, 'Flachfisch' (vlacvisch), and 'Sporden', ${ }^{12}$ as well as other fish species of the Gadidae family, such as saithe (Germ. Köhler, sej; Pollachius virens), common ling (Germ. Leng; Kongenlangen, gemeine Langen, soltelungen; Molva molva) and tusk (torsk, cusk; Germ. Lumb, Brosme; Brosme brosme). ${ }^{13}$ Ling is frequently specified separately in the Lübeck and Hamburg documents from the fourteenth to the seventeenth centuries, probably because of their readily recognizable differences of a more slender shape and greater total length compared to cod. ${ }^{14}$

In each case, the caught fish were decapitated, gutted, and left to dry on racks. Anatomically, this results 


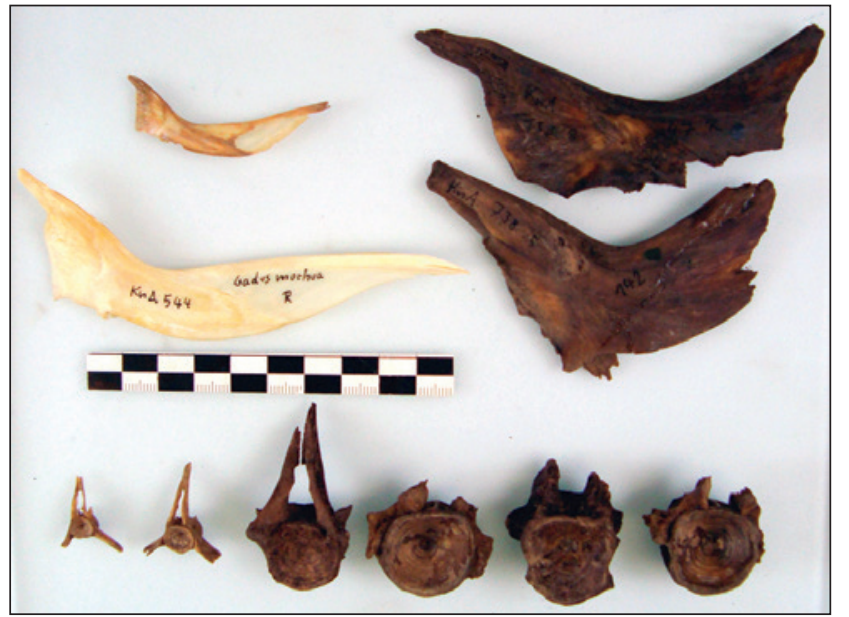

Fig. 5. Bremen, site 253-Am Wall, cod (Gadus morhua), cleithra (above) and vertebrae (below) of different size classes: light cleithra (top left) are reference specimens (KnA 89.2, 544), the larger one is from an individual of $71 \mathrm{~cm}$ total length, all other bones are finds (photo by author; from Küchelmann 2014a, 22, fig. 13b; Bischop and Küchelmann 2018, fig. 8).

in a clear separation of the body parts, with skull elements remaining at the production sites in the north and postcranial parts (the spine and shoulder girdle elements) being shipped as stockfish to the south. In stockfish remains from Hanseatic cities in Germany, we may therefore expect postcranial elements of Gadidae, but not skull elements (Fig. 5). However, there are exceptions. In the case of 'Rotscher', the fish was cut lengthwise into halves up to the tail, and most of the spine was extracted from the body, leaving

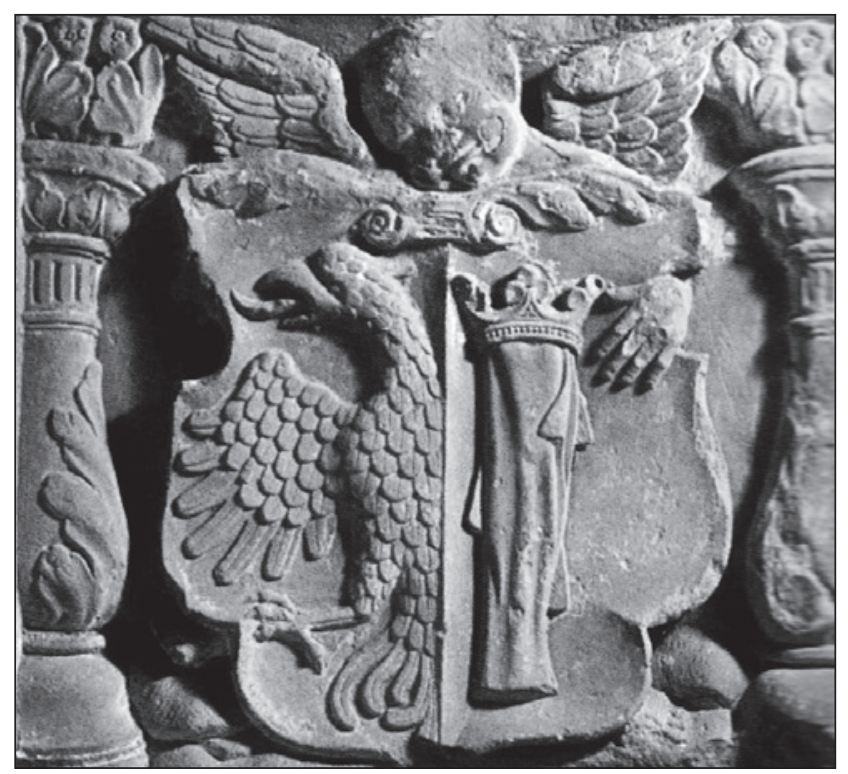

Fig. 6. 'Stein der Bergenfahrer', stone of the community of the Bergen merchants from Bremen dated c. 1550 (from Christiansen 1998, 66). only a few caudal vertebrae in the shipped fish. ${ }^{15}$ This means that we would not be able to find many remains some hundred years later. It is not clear what happens with the shoulder girdle elements in 'Rotscher'. More research is necessary to define the different historical types and qualities of stockfish, their geographical and diachronic distributions, differences in processing methods and subsequent recovery potential, and possible assignment to zoological species. ${ }^{16}$

A good illustration of the demand for standardized processing methods, quality management, and the pressure on the fishermen is a decree from 1494, which prohibited the drying of fish on rock cliffs and demanded that they be hung on racks to dry. The reason was that the fish sometimes do not dry completely on the surface, causing risk of putrescence. Violation would exclude fisherman from being Hanseatic customers. ${ }^{17}$ An impression of the degree of standardization is also given by the representation of decapitated, processed cod on various seals and coats of arms from Iceland and Hanseatic cities (Fig. 6).

\section{Size classes}

The quality control systems of the market economy impose not only standardized processing methods on fishermen, but also a necessity to deliver fish of a certain size. An average catch would comprise individuals of widely ranging age and size according to the normal demographic structure of the fish population. Small individuals, however, would require the same production steps and thus the same amount of work and time for processing as large individuals, but they are sold as lesser quality for a lesser price. Hanseatic merchants distinguished different size classes (koningeslobben, gemeine lobben, rackvische, lotvische, halfwassene, kropelinge and titlinge), and there were centuries-long debates between fishermen, merchants and consumers about improperly packed or sorted size classes. ${ }^{18}$ We may also refer to weight and packing units agreed upon between producers and Hanseatic merchants documented in Hanseatic sources. If we apply sixteenth-century Icelandic units, for instance, five Rundfisch were equivalent to one Fordung and weighed approximately ten pounds. Forty Rundfisch were equivalent to eight fordung or one wete..$^{19}$ In Bergen, fish shipped in bulk were measured in wage, which is equivalent to $35-40$ pounds. In the seventeenth century, 65-100 wage of Rundfisch were equal to one last (two metric tons)..$^{20}$ The resulting archaeozoological expectation is that stockfish 


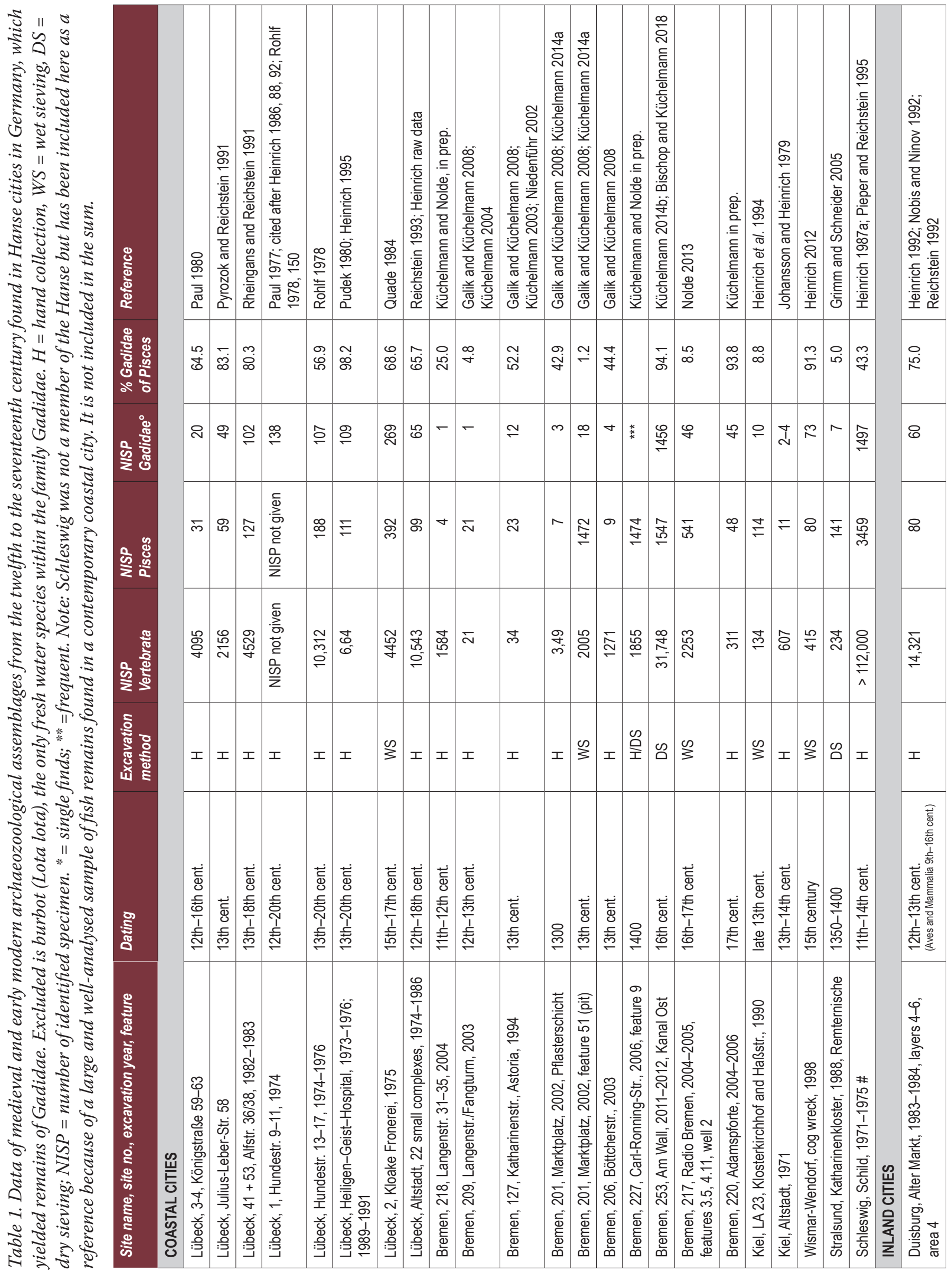




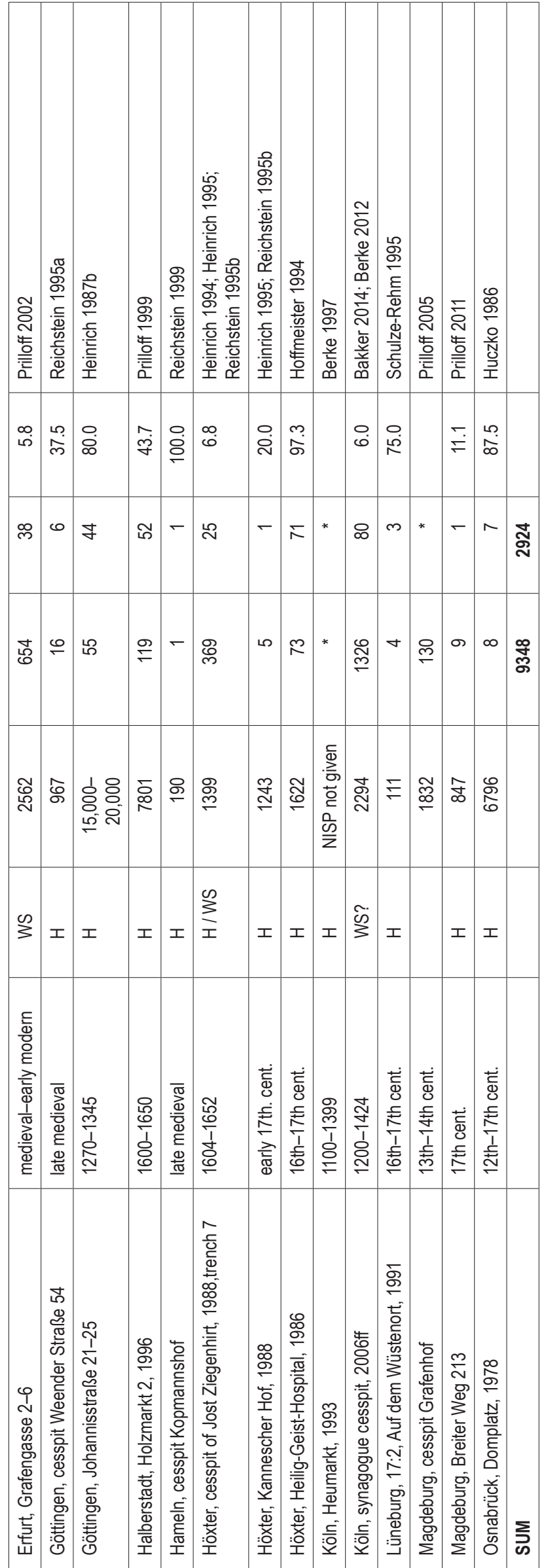

remains should display a clearly sorted pattern of size classes with bones from large adult individuals being heavily overrepresented and remains of small juvenile individuals missing.

\section{Geographical distribution}

A third line of evidence is the geographical distribution of the different Gadidae species used to produce stockfish. Cod and haddock inhabit North Atlantic waters and the shallow parts of the North Sea, with cod also living in the Baltic. Juvenile cod grow up in the shallow Wadden Sea area of the North Sea, and adults tend to move to deeper waters. In contrast, the natural range of ling, tusk and saithe does not include the shallow parts of the German Bight. ${ }^{21}$ As a result, local fishermen on the German North Sea coast can catch cod and haddock, while fishermen from around Lübeck can catch cod only. ${ }^{22}$

Applied to archaeozoological assemblages in Germany, this means that cod and haddock found in coastal sites may either be from local fisheries or North Atlantic imports. Fish from local fisheries should be detectable by the presence of cranial elements and a much wider range of age and size classes that is closer to the natural age distribution. On the other hand, finds of ling, tusk and saithe are almost certainly imported, they should be from large adult individuals, and cranial elements should be missing. Since the long-distance transport of fresh fish was nearly impossible until the twentieth century, marine fish could reach inland sites in only a preserved state. The expectation is that we should find a clear stockfish pattern at inland sites with large individuals prevailing and skull elements missing.

The historic documents can add evidence to this thread of research as well. Icelandic stockfish are said to have harder flesh and are specified in Lübeck documents as noptzen (nuptzen, nopsches). Fish from the Shetlands are declared to be of lesser quality, and several merchants seem to have mixed Shetland with Lofoten fish to increase their profit, a practice that was subsequently prohibited. ${ }^{23}$ Whether there was a real difference in quality or if this was only a marketing strategy of Bergen monopolists would be interesting to know.

\section{Catching stockfish in the cities}

Although the potential of in-depth studies of fish bone assemblages is promising, the amount of available 
Table 2. Gadidae, skeletal element distribution (only sites with a number of Gadidae > 10). *Skeletal element details are given only for 1201 specimens with exact find locations that could be identified to the species level.

\begin{tabular}{|c|c|c|c|c|c|c|c|}
\hline Site & Dating & n Gadidae & $n$ cranial & $\%$ cranial & $n$ postcranial & $\%$ postcanial & Reference \\
\hline Lübeck, Königstraße 59-63 & 12th-16th cent. & 20 & 0 & 0 & 20 & 100.0 & Paul 1980 \\
\hline Lübeck, Julius-Leber-Str. 58 & 13th cent. & 49 & 5 & 10.2 & 40 & 81.6 & $\begin{array}{l}\text { Pyrozok and Reichstein } \\
1991\end{array}$ \\
\hline Lübeck, Alfstr. 36/38 & 13th-18th cent. & 102 & 13 & 12.7 & 86 & 84.3 & $\begin{array}{l}\text { Rheingans and Reichstein } \\
1991\end{array}$ \\
\hline Lübeck, Hundestr. 13-17 & 13th-20th cent. & 107 & 10 & 9.3 & 97 & 90.7 & Rohlf 1978 \\
\hline $\begin{array}{l}\text { Lübeck, Heiligen-Geist- } \\
\text { Hospital }\end{array}$ & 13th-20th cent. & 100 & 89 & 89.0 & 11 & 11.0 & Pudek 1980 \\
\hline Lübeck, cesspit Fronerei & 15th-17th cent. & 269 & 13 & 4.8 & 256 & 95.2 & Quade 1984 \\
\hline Lübeck, 22 small complexes & 12th-18th cent. & 65 & 12 & 18.5 & 53 & 81.5 & Heinrich, raw data \\
\hline $\begin{array}{l}\text { Bremen, 127, } \\
\text { Katharinenstr., Astoria }\end{array}$ & 13th cent. & 12 & 1 & 8.3 & 11 & 91.7 & $\begin{array}{l}\text { Galik and Küchelmann } \\
\text { 2008; Küchelmann } 2003\end{array}$ \\
\hline Bremen, 201, Marktplatz & 13th cent. & 18 & 2 & 11.1 & 16 & 88.9 & $\begin{array}{l}\text { Galik and Küchelmann } \\
\text { 2008; Küchelmann 2014a }\end{array}$ \\
\hline Bremen, 253, Am Wall & 16th cent. & 1456 & 36 & 2.5 & 1419 & 97.5 & $\begin{array}{l}\text { Küchelmann 2014b; } \\
\text { Bischop and Küchelmann } \\
2018\end{array}$ \\
\hline $\begin{array}{l}\text { Bremen, 217, Radio } \\
\text { Bremen }\end{array}$ & 16th-17th cent. & 46 & 10 & 21.7 & 36 & 78.3 & Nolde 2013 \\
\hline Bremen, 220, Adamspforte & 17th cent. & 45 & 0 & & 45 & 100.0 & Küchelmann, in prep. \\
\hline $\begin{array}{l}\text { Kiel, LA 23, Klosterkirchhof } \\
\text { and Haßstr. }\end{array}$ & late 13 th cent. & 10 & 0 & 0 & 10 & 100.0 & Heinrich et al. 1994 \\
\hline Schleswig, Schild* & 11th-14th cent. & 1201 & 117 & 9.7 & 1080 & 89.9 & Heinrich 1987a \\
\hline Duisburg, Alter Markt & 12th-13th cent. & 60 & 3 & 5.0 & 57 & 95.0 & Heinrich 1992 \\
\hline $\begin{array}{l}\text { Göttingen. Johannisstraße } \\
21-25\end{array}$ & $1270-1345$ & 44 & 2 & 4.5 & 42 & 95.5 & Heinrich 1987b \\
\hline $\begin{array}{l}\text { Höxter, cesspit of Jost } \\
\text { Ziegenhirt }\end{array}$ & $1604-1651$ & 25 & 0 & 0 & 24 & 96.0 & Heinrich 1995 \\
\hline Höxter, Heilig-Geist-Hospital & 16th-17th cent. & 71 & 3 & 4.2 & 68 & 95.8 & Hoffmeister 1994 \\
\hline Halberstadt, Holzmarkt 2 & $1600-1650$ & 52 & 0 & 0 & 52 & 100.0 & Prilloff 1999 \\
\hline SUM & & 3752 & 316 & & 3423 & & \\
\hline
\end{tabular}

data show that the possibilities for such analyses are rare. Table 1 lists archaeozoological assemblages from Hanse cities where remains of fish from the cod family (Gadidae) have been found. ${ }^{24}$ The compilation shows that the material available for analysis is still rare. All Gadidae bones from Hanse cities together add up to less than 3000 specimens, with only six sites yielding more than a hundred finds and only one having a statistically safe representation of more than thousand bones. ${ }^{25}$ Some data are available for Lübeck and some for Bremen (although mainly unpublished material, unfortunately). Hamburg is currently a blank space on the archaeozoological map. ${ }^{26}$ This is particularly regrettable since archival sources indicate that merchants from Hamburg and Bremen were the main actors in the Hanseatic trade with the North Atlantic. ${ }^{27}$ Of particular interest are Gadidae finds from inland Hanse cities, which occur in low frequencies but appear regularly, even in hand-collected assemblages (Table 1).

It is obvious that there is a need for much more fish bone material from excavations in Hanse cities, which should be carried out with finer methods and higher resolution to be able to draw wider conclusions. The reason for the lack of evidence is mainly methodological. Until the second half of the twentieth century, bones were generally not regarded as items worth keeping and analysing in archaeological research. Even when this changed gradually, many excavators did not invest the expensive and time-consuming effort of sieving out small bones. Nearly all excavations in 


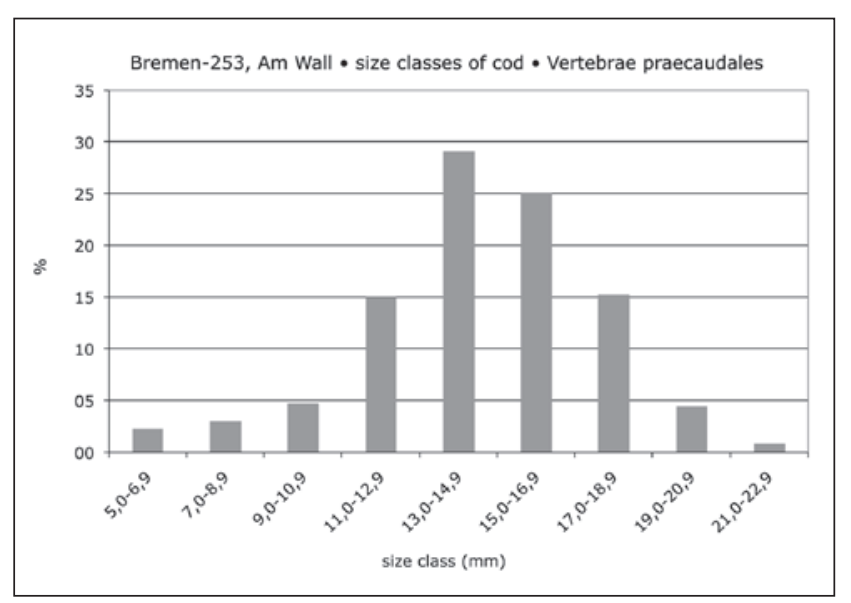

Fig. 7. Size distribution of cod precaudal vertebrae from the Bremen, site 253-Am Wall $(n=354)$ (from Küchelmann 2014a, 22, fig. 13a; Bischop and Küchelmann 2018, 142, fig. 9).

Bremen and Lübeck thus far have involved hand collection, with only a few soil samples ultimately being sieved. Most were even rescue excavations with limited time and financial resources.

In contrast, North Atlantic production sites have been excavated elaborately: 'substantial, well-dated, and systematically sieved archaeofauna are now available from most parts of the Hanseatic Atlantic zone. ${ }^{28}$ In the present state of research, we can only try to obtain the most out of the limited data available. In Table 1 , the frequency of fish bones within the vertebrate remains should first be considered. This frequency is usually rather low unless sieving has been applied, which represents the marked influence of the recovery method. Secondly, the frequency of Gadidae within the fish samples is most instructive. If we concentrate on coastal sites with a number of identified specimens (NISP) of more than a thousand vertebrate and more than fifty fish remains, all sites in Lübeck and the site Bremen-253 display more than 50 \% Gadidae among the total fish remains. ${ }^{29}$ This is surely a methodological artefact of hand-collected assemblages to a certain degree, as bones of large Gadidae are more preservable and easier to recover than bones of smaller species and individuals. As mentioned, however, even the regular occurrence of large Gadidae is itself strong evidence for the existence of dried stockfish.

What needs to be emphasised once more is that a single cod bone is not evidence for a North Atlantic trade. What we need to detect are patterns of a statistical nature, which emerge only within large assemblages - patterns such as species abundances, skeletal element ratios, and size-class groupings. Despite the low number of finds, a surprisingly regular pattern is evolving. In all but one site for which skeletal element data are available, the postcranial elements are clearly overrepresented (Table 2). The only outlier is the site Lübeck, Heiligen-Geist-Hospital, where cranial elements prevail. Here, remains of fresh Baltic cod seem to have been deposited. The most obvious and most reliable examples are the sites Bremen-253 (Am Wall) and Lübeck-2 (Fronerei), which were sieved and yielded the largest amount of Gadidae bones. Postcranial remains made up more than $95 \%$ in these cases. It is also evident that cranial elements are present in most coastal sites in low percentages, making it likely that fresh local Gadidae have been caught and consumed. If we look at the inland sites, Höxter and Halberstadt match with expectations, as all Gadidae bones found are postcranial elements, thus supporting the assumption that they stem from stockfish. While the general picture also fits for Duisburg, the three cranial cod bones found are less easy to interpret. How could fresh cod have found its long way to Duisburg without becoming inedible in the thirteenth century? Perhaps in smoked form?

Osteometric measurement data are only available for sites in Lübeck (Julius-Leber-Straße 58), Bremen (253, Am Wall), Duisburg (Alter Markt) and Höxter (cesspit of Jost Ziegenhirt). In Bremen-253, the archaeozoological record fits well with the expectations of stockfish import: according to size regressions from precaudal vertebrae, the size range of individual cod varied from 40 to $145 \mathrm{~cm}$ in total length (TL), and $84.5 \%$ of the vertebrae belonged to cod with total lengths between 75 and $120 \mathrm{~cm}$, with $94.6 \%$ from individuals over $64 \mathrm{~cm}$. Thus, the majority of cod bones (over $90 \%$ ) belong to large adult individuals (Fig. 7). ${ }^{30}$ Small juvenile fish and cranial elements are present in small quantities (Fig. 5), which points toward a local fishery. ${ }^{31}$ In Lübeck, the size range of cod was $95-125 \mathrm{~cm}$ TL $(\mathrm{n}=18) .{ }^{32}$ In Duisburg, all fourteen cod vertebrae came from quite large individuals of $85-120 \mathrm{~cm} \mathrm{TL},{ }^{33}$ and cod bones from Höxter derive from mid-sized individuals of $40-70 \mathrm{~cm} \mathrm{TL} .{ }^{34}$ In Duisburg, three vertebrae from large ling (TL 100-140 cm) and one from a large saithe (TL $100 \mathrm{~cm}$ ) were found. ${ }^{35}$ Cod vertebrae from eleventh- to fourteenth-century Schleswig show an even more pronounced dispersal towards large adult individuals (Fig. 8).

As a last result, we may look at the frequencies with which different Gadidae species appear at different sites (Fig. 9). The graph clearly shows the dominance of cod in all cases, while the other species are of minor importance. These and future data on the frequencies 


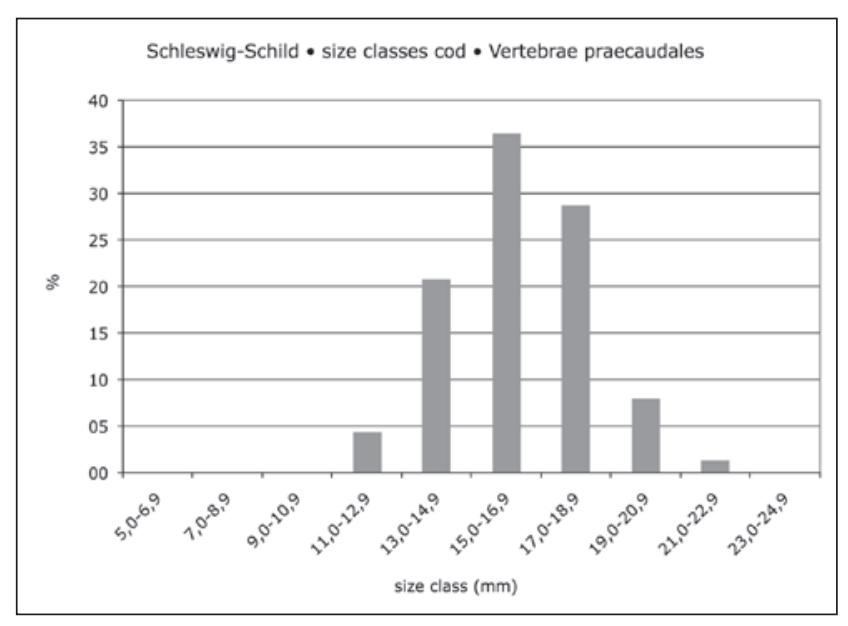

Fig. 8. Size distribution of cod precaudal vertebrae from the site Schleswig, Schild $(n=442)$ (data from Heinrich 1987a, 99).

of Gadidae species may someday be compared with species frequencies given in Hanseatic freight lists, such as those mentioned for the Bergen-Lübeck trade route. $^{36}$

An interesting aspect appears when comparing the results of the Hanse cities with Schleswig, which was not a member of the Hanse but was obviously integrated in overseas trade routes, as the pattern of Gadidae remains suggests. Postcranial elements prevail, representing $89.9 \%$ of the bone finds (Table 2), and there is evidence for species not native to the Baltic, such as saithe and haddock, which show a clear predominance of large individuals (Fig. 8). But at $43.3 \%$, the amount of Gadidae within the fish bone sample from Schleswig is lower than in other coastal cities (Table 1), which presumably results from of a significant proportion of the local fishery in the Baltic Sea. Furthermore, a diachronic development appears in Schleswig: in material from the early phase (the eleventh to the twelfth centuries), the percentage of cod bones is higher, the cods are larger, and cranial elements are rare. In later features (from the thirteenth to the fourteenth centuries), smaller individuals and cranial elements are more prevalent. ${ }^{37}$ This development can be interpreted as a reflection of Schleswig losing its importance as an overseas trade port to Lübeck and the Hanse.

\section{Comparing historical and archaeozoological fish data}

Finally, we compare the historical information available for Bremen with the archaeozoological information. A debt register from the Bremen merchant Claus Monnickhusen from 1558 surviving in the Staatsarchiv
Bremen lists an amount of 150 wete of stockfish (equivalent to 6000 individual fish). This was purchased from over ninety fishermen in his booth in Kumbaravogur (Kummerwage) in Iceland and shipped back to Bremen in the years 1557 and $1558 .{ }^{38}$ According to Hofmeister, ten to fifteen merchants travelled aboard large vessels to Iceland in the sixteenth century, although not all vessels were that large. Approximately twenty-five ships sailed from Bremen to Iceland per year. ${ }^{39}$ Based on these figures, 250-375 merchants could have shipped 0.75-1.12 million fishes from Iceland per year.

Another option is estimation by freight weight: the average cargo capacity of a Hanse ship sailing to Iceland was sixty last. ${ }^{40}$ According to Lübeck documents from 1599, 1602, and 1609, one last was equivalent to hundred wage or fourteen Lübeck tons, and one wage was equivalent to thirty-five pounds. ${ }^{41}$ If five Iceland Rundfisch weighed ten pounds, ${ }^{42}$ one wage would be 17.5 Rundfisch, and one last would comprise 1750 fish. One Lübeck ton would weigh 250 pounds and contain 125 fishes. The cargo capacity of one ship of sixty last would then be 105,000 Rundfisch, and twenty-five ships would be able to export 2.62 million fish per year from Iceland. Hofmeister gives a slightly lower amount extracted from Hamburg sources, with one last being equal to twelve Hamburg tons, 1200 fishes, or two metric tons. ${ }^{43}$ Thus, one Hamburg ton would have contained hundred fishes or two hundred pounds. According to these figures, one ship of sixty last could carry 72,000 fishes, and twenty-five ships could have transported 1,8 million fishes. ${ }^{44}$ Regardless of the calculation used, the amounts are impressive and presumably influential on the Atlantic cod population. ${ }^{45}$

The Gadidae bones recovered from the site Bremen-253 date to the second half of the sixteenth century, when Claus Monnickhusen imported his fish from Iceland. Especially intriguing is that there is a justified possibility that part of these cod and ling bones might have been part of the cargo of this historically known citizen in 1557 or 1558 . With 1456 Gadidae remains, the site Bremen-253 yielded the third highest amount of Gadidae ever recovered in an archaeological excavation in Germany thus far, ${ }^{46}$ exceeded only by Haithabu ${ }^{47}(\mathrm{n}=1771)$ and Schleswig ${ }^{48}(\mathrm{n}=1497)$. Nevertheless, if we start the calculation with the actual found bones, the provable amount of fish is rather different from the quantity that can be calculated from historic documents. In Bremen-253, 1214 Gadidae vertebrae were found. One cod has fifty-one to fiftyfive vertebrae, ${ }^{49}$ so the number of provable individuals ranges from 22-1214 fish (depending on whether we 


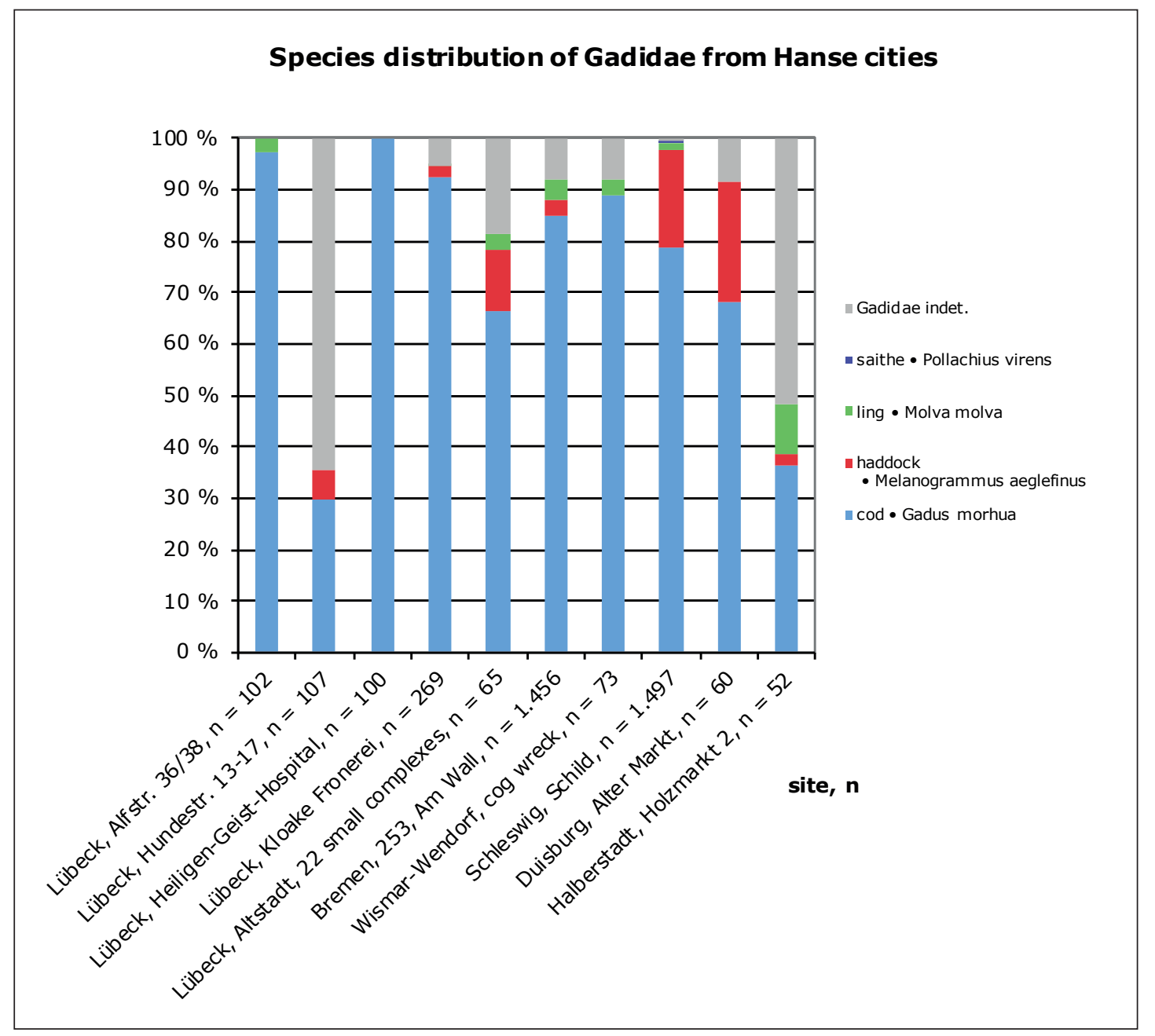

Fig. 9. Species distribution of Gadidae in Hanse cities (only sites with more than fifty Gadidae). calculate the minimum number of individuals (MNI) or assume that each vertebra represents a single individual). Furthermore, 188 cleithra of Gadidae were recovered, of which each individual possesses two. They have not been separated by body-side yet, but the number of deducible individuals would lie between 94 and 188. This calculation may seem academic, but it gives at least an impression of the enormous gap between the historic documents and the archaeozoological finds. Perhaps someday we will be able to obtain results that are at least a bit closer to each other.

\section{Bio-molecular studies}

With bio-molecular methods becoming more and more elaborate and the amount of reference data increasing, the potential and reliability of bio-molecular approaches is growing continuously. Stable isotope analyses enable conclusions about a creature's geographical habitat via characteristic isotope patterns of certain soil or water bodies, which are incorporated into body tissues during the creature's life-cycle.
Ancient DNA studies can also give clues about the provenance of Gadidae bones if it is possible to assign them to genetically distinguishable sub-populations. Furthermore, the application of statistical demographic models allows for the recognition of demographic changes and developments. Some related research in this direction may be mentioned here.

A range of questions have been addressed within the 'Medieval Origins of Commercial Sea Fishing Project' at the Universities of York and Cambridge, and some of the results have been published already. ${ }^{50}$ David Orton et al. demonstrate diachronic differences within the provenance of cod bones from several Baltic sites, with the quantities of bones of North Atlantic origin increasing from the thirteenth to the fourteenth centuries. ${ }^{51}$ In Britain, James Barrett et al. found only local southern North Sea isotopic patterns until the eleventh century. ${ }^{52}$ Since then, North Atlantic signatures first appear in large towns, such as York and London. In the fifteenth to the sixteenth centuries, North Atlantic signatures are widespread, and they are even dominant in large cities such as Cambridge and London (Fig. 10). 
Fig. 10. Provenance of cod vertebrae and cleithra $(n=129)$ from England and Belgium (ninth to eighteenth century) established via $13 C$ and $15 \mathrm{~N}$ isotopes (from Barrett et al. 2011, 1520, fig. 4).

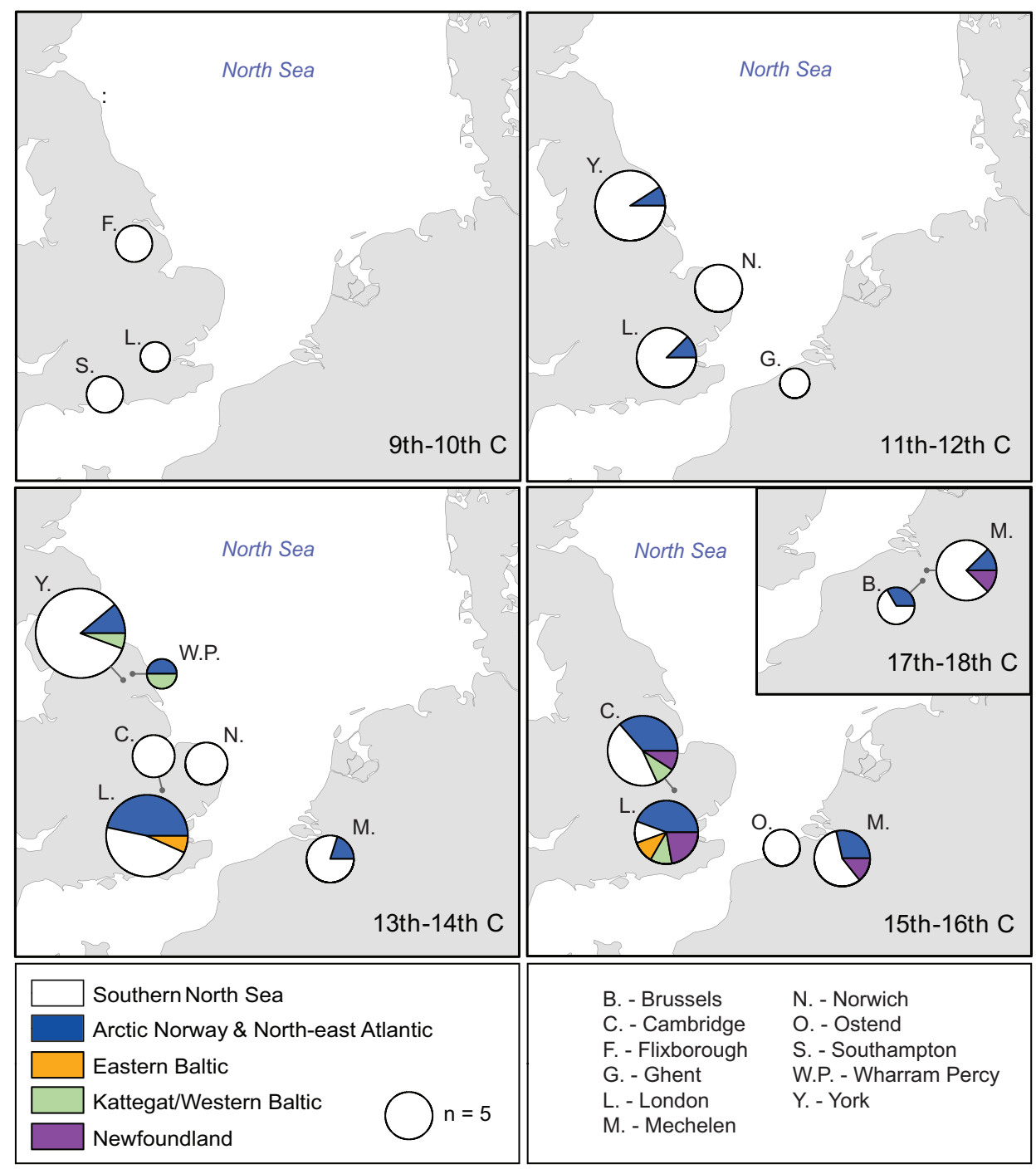

Cod bones from four sites in Bremen (site nos 127, 201, 206, and 218; for details, see Table 1) have been included in the research, but most of the specimens sampled unfortunately did not give usable measurements. ${ }^{53}$ In a combined morphological, osteometrical, isotopic and aDNA approach, Guðbörg Ólafsdóttir et al. found indications for major changes in the cod population around Iceland. These include a genetic bottleneck effect between 1400 and 1500, with a subsequent loss of genetic diversity and changes in the average and variation of size and age within the population. ${ }^{54}$

\section{Excursus: iconography}

This paper would not be complete without at least a short discussion of the possibilities of an archaeozoological evaluation of iconographical evidence of the stockfish trade. The most prominent and certainly the most instructive example is the Icelandic coat of arms, which was officially used with slightly different
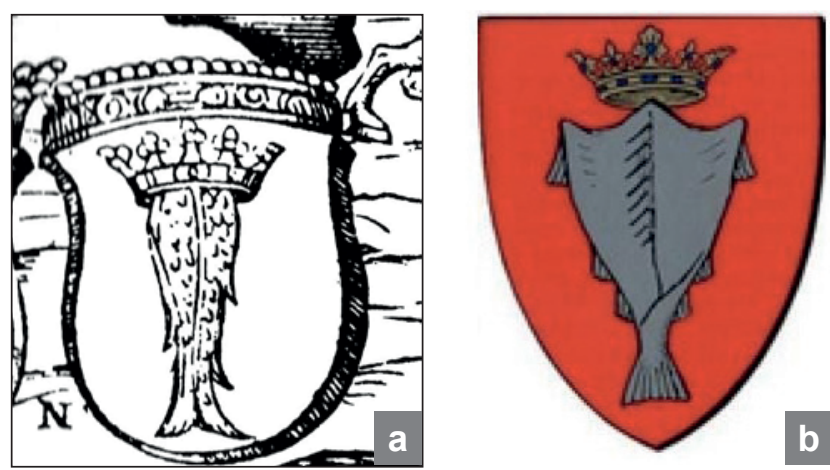

Fig. 11. a) Coat of arms of Iceland, as depicted on the Carta Marina by Olaus Magnus, b) coat of arms of Iceland from 1820-1903 (from Thorlacius 1991).

designs from at least 1593 until 1903 and depicts a processed cod (stockfish) with a crown (Fig. 11). ${ }^{55}$ The nineteenth-century version in particular (Fig. 11b) reveals a remarkable amount of anatomical detail. The fish is split up ventrally, and the double semi-lunar margins at the top show the location of the left and right 
cleithra, the largest bones of the shoulder girdle. The spine and attached costae are indicated in the centre. The left and right pectoral fins (top), ventral and anal fins (left bottom), and two separate dorsal fins (right bottom) identify the fish most certainly as cod. Tusk and ling have a continuous dorsal and ventral fin-line instead of separated fins. The only other species that cannot be excluded with certainty are saithe, Atlantic pollock (Pollachius pollachius), and haddock. Other examples are less detailed, but they all display separate fins. A good example from a Hanse city is the 'Stein der Bergenfahrer' dated to 1550 , the coat of arms of the community of Bremen merchants sailing to Bergen, which is now an exhibit in the Focke-Museum in Bremen (see Fig. 6). There are also seals with cod illustrations from Lübeck (c. 1415) and Hamburg (c. 1500). ${ }^{56}$ More research is warranted, and collaboration between historians and zoologists may give fruitful results.

\section{Conclusion}

Because the quantity of fish remains recovered from Hanse cities in Germany thus far is very low, wider detailed conclusions cannot be drawn in the present state of research. Diachronic studies within particular cities are not possible, nor are comparisons between Hanse cities. Quantitative analyses are completely out of range. The scarce evidence provides only a superficial impression. Nevertheless, overall patterns are visible, which are generally consistent with the assumptions about patterns for imported stockfish outlined above: high frequencies of Gadidae within the fish remains of coastal Hanse cities, overrepresentation of postcranial skeletal elements, prevailing remains of large, adult Gadidae, and isotopic profiles proving the North Atlantic origin of Gadidae finds support the hypothesis. However, it is currently impossible to discriminate between imports from Bergen, Iceland, Shetland, and the Faroes, although not unthinkable in general. The application of isotopic and aDNA analyses may well enable us to assign fish remains found in Hanse cities to a certain geographic catch region or genetic sub-population in the future.

\section{Acknowledgements}

First of all, I would like to express my regards to Dirk Heinrich, who taught me everything I know about fish bones, suggested me for the conference in Avaldsnes, shared numerous valuable and even unpublished sources with me, and critiqued the manuscript. I am also grateful to Norbert Benecke, Angela von den Driesch, and Dirk Heinrich for the opportunity to use the at the time of writing still unpublished database of European faunal remains. Ralf-Jürgen Prilloff provided me with several publications of Hanseatic inland sites that would have been difficult to obtain access to without his kind help. Natascha Mehler, Mark Gardiner, and Endre Elvestad are to be honoured for having organized such a wonderful and fruitful conference.

\section{Endnotes}

${ }^{1}$ Stockfish will be used here as an umbrella term for dried fish of the cod family (Gadidae) in general.

${ }^{2}$ Lyman 1994, 417-33; Müller 1992, 117-159.

${ }^{3}$ For example, Clason and Prummel 1977; Heinrich 1999a, 165f.; Lepiksaar and Heinrich 1977, 5, $13 \mathrm{ff}$.

${ }^{4} \mathrm{~A}$ good example is the recently excavated first millennium AD site of Wijnaldum-Tjitsma, Netherlands, where the complete sediment has been sieved (Prummel et al. 2013). Within a NISP (no. of identified specimen) of 11,912, fish made up $43.7 \%$, birds $14.8 \%$, and mammals $41.4 \%$. In hand-collected sites, fish bones are often missing completely; if they are present, they are usually single finds not exceeding a few per cent.

${ }^{5}$ For more detailed insights into archaeozoological methods in general see e.g. Davis 1995; Lyman 1994; O'Connor 2000; Rackham 1994; for archaeoichthyology in particular: Casteel 1976. For fish bone identification criteria, see e.g. Libois and Hallet-Libois 1988; Mehner 1990; Perdikaris et al. 2004; Radu 2005 or Watt et al. 1997.

${ }^{6}$ See e.g. Morales and Rosenlund 1979; Heinrich 1987a; Rojo 1986.

${ }^{7}$ In the instructive examples of the medieval sites Eketorp III (Öland, Sweden) and Menzlin (Mecklenburg-

Vorpommern, Germany), over $90 \%$ of the recovered fish bones were from herring, c. $90 \%$ of which consisted of skull elements. Both sites display a rather clear pattern of a production site, where large amounts of herring have been decapitated, with the heads dumped and the bodies traded elsewhere (Benecke 1982).

${ }^{8}$ Heinrich 1986, 87; Heinrich 1987a, 117; Perdikaris 1997.

${ }^{9}$ Perdikaris 1997, 506.

${ }^{10} \mathrm{Ibid}$.

${ }^{11}$ Skivenes 2005.

${ }^{12}$ Sporden, Sporren, Schorden, or Spure are pieces from the neck or tail of the dried fishes that are broken off to allow for better packaging in barrels, which are collected separately; see Bruns 1900, LXXX; Bruns 1953, 49; Hammel-Kiesow 2005, $131 f$.

${ }^{13}$ The quantity of traded cod exceeded the other species by far. The quantities of the different types of stockfish varied according to different sources and probably even in different years. In 1636, for instance, 'Rotscher' made up the largest quantity shipped from Bergen, whereas 'Rundfisch' was shipped in only small quantities (Bruns 1953, 138f). By contrast, the Danish customs rolls for the period of 1650-1654 list 'Rundfisch' as the largest 
quantity exported from Bergen (Hammel-Kiesow 2005, 132). Haddock (Germ. Schellfisch; Melanogrammus aeglefinus) is another species of the cod family (Gadidae) rarely specified in Hanse documents but has definitely been processed as stockfish. Apart from Gadidae, other fish species are occasionally mentioned in Hanse documents in small quantities, such as sea trout (Germ. Meerforelle; Ore; Salmo trutta), salmon (Germ. Lachs; Salmo salar), halibut (Germ. Heilbutt, Raff, Rekeling; Hippoglossus hippoglossus), ray (Germ. Rochen; Raja sp.) and herring (Germ. Hering; Clupea harengus) (Baasch 1889, 72; Bruns 1900, LXXXIIf. and LXX-LXXXXI; Bruns 1953, 50; Hammel-Kiesow 2005, 132; Heinrich 1987a, 93).

${ }^{14}$ Baasch 1889, 72-76; Bruns 1900, LXXII-V.

${ }^{15}$ Ibid., LXXXVI; Heinrich 1987a, 93, 119; Heinrich 1955, 387.

${ }^{16}$ Other examples of terms given in historic sources requiring further investigation towards taxonomic species and product qualities are Klippfisch, Mutfisch, Hartfisch, Hoevetfisch, Gildefisch, Tidtling, strumulus, halfwassene and uthshot (Baasch 1889, 72-76; Bruns 1900, LXXXVII, LXXX; Lorenzen-Schmidt 2013).

${ }^{17}$ Bruns 1900, LXXIf., LXXVI. In 1494, the fishermen promised, 'Dat se na desseme dage neynen rotscher iffte visch uppe den klippen drogen willen, sunder na older wonheyt uphengen und one also drogen laten' (that after this day they will dry neither rotscher nor fish upon the cliffs but instead hang them according to old custom and let them dry; transl. by author).

${ }^{18}$ Bruns 1900, LXXII-LXXV.

${ }^{19}$ Hofmeister 2000a, 52; Hofmeister 2001, 35.

${ }^{20}$ Bruns 1953, 16f.; Hammel-Kiesow 2005, 127, 132; Skivenes 2005, $105 f$.

${ }^{21}$ Adult cod live in depths of up to $600 \mathrm{~m}$, haddock up to $200 \mathrm{~m}$, saithe up to $250 \mathrm{~m}$, tusk between 150 and $550 \mathrm{~m}$, and ling between 100 and $400 \mathrm{~m}$. Ling and tusk can live at depths of up to $1,000 \mathrm{~m}$, and tusk avoids shore areas (Muus and Nielsen 1999, 120, 126, 132, 134ff.; see also http://www.fishbase.org).

${ }^{22}$ The underlying assumption here is that the native distribution of species has not changed significantly in the last thousand years.

${ }^{23}$ Bruns 1900, LXXXI.

${ }^{24}$ For the compilation, it has been attempted to monitor all available analysed medieval to early modern (twelfth to seventeenth century) archaeozoological inventories from 153 Hanse cities in Germany listed in the map of the Hanse (http://www.kalimedia.de/Hansekarte.html) for remains of Gadidae. The assemblages have been checked using a site list from Benecke (1994, 296-305), a database assembled by Norbert Benecke, Angela von den Driesch and Dirk Heinrich (see Benecke 1999; Benecke et al. 2016), and the authors' reference database (http://www. knochenarbeit.de/literatur). There may be some Gadidae bones that escaped attention, but likely not many.

${ }^{25}$ There are elaborate reports on fish bone assemblages from sites in Germany, but these either do not fit in the time range of the Hanse (e.g. from Elisenhof, Hitzacker or Haithabu; see Heinrich 1985; Heinrich 1994; Heinrich 2006; Lepiksaar and Heinrich 1977; von den Driesch 1982) or are not from Hanse cities (Schleswig or Mansfeld, Heinrich 1987a; Heinrich 2008). We may look forward to the results of recent elaborate excavations in the city centre of Lübeck, Gründerviertel.

${ }^{26}$ There seems to be only one archaeozoologically analysed assemblage from Hamburg at present from the site Kleine Bäckerstraße (Herre 1950a; Herre 1950b). Only one short hint in Herre (1950a, 7) points towards Gadidae. Historical data from Hamburg may give more detailed information. The Beginenkonvent, the Beguinage in the Steinstraße, for instance, bought 15 tons of 'Rotscher' in the years 1504-1506, supplying a household of 30-45 people (Lorenzen-Schmidt 2013).

${ }_{27}$ Baasch 1889; Gardiner and Mehler 2007; Hofmeister 2000a; Hofmeister 2000b; Hofmeister 2001.

${ }^{28}$ Perdikaris 1997.

${ }^{29}$ The sites that fall out of the pattern here are Bremen-201 (market place, feature 51) and Bremen-217. In both cases, the majority of fish bones stem from special discrete features that are most likely the results of single, shortterm deposition events. Feature 51 from the market place was a small pit $(50 \times 50 \mathrm{~cm})$ filled up with fish bones, mainly herring and members of the carp family (Cyprinidae), which was probably used as a dump for market leftovers. Feature 3.5 from the site Bremen-217 situated in an artisan quarter contained more than $70 \%$ eel (Anguilla anguilla) remains. The site Bremen-227 has not been analysed completely yet.

${ }^{30}$ Küchelmann 2014b, 22f.; Bishop and Küchelmann 2018, $142 \mathrm{f}$.

${ }^{31}$ Atlantic cod reaches sexual maturity within four to fifteen years and with a total length of approximately $60-70 \mathrm{~cm}$. Its maximum length is $150 \mathrm{~cm}$; thus, individuals of $145 \mathrm{~cm}$ in total length were certainly very old (Heinrich 1987a, 101f.; Muus and Nielsen 1999, 120ff.; http://fishbase.org/summary/Gadus-morhua.html, access date 01.12.2017).

${ }^{32}$ Pyrozok and Reichstein 1991, 187.

${ }^{33}$ Heinrich 1992, 297.

${ }^{34}$ Heinrich 1995, 388.

${ }^{35}$ Heinrich 1992, 298 f.

${ }^{36}$ Hammel-Kiesow 2005; Skivenes 2005.

${ }^{37}$ Heinrich 1986, 89; Heinrich 1987a, 114-117, 179-182; Heinrich 1999b, 346, 350.

${ }^{38}$ Hofmeister 2000a; Hofmeister 2001.

${ }^{39}$ Hofmeister 2000b, 41-44.

${ }^{40}$ Ibid., 41.

${ }^{41}$ Bruns 1953, 16f.; Hammel-Kiesow 2005, 127, 132.

${ }^{42}$ Hofmeister 2000a, 52; Hofmeister 2001, 35.

${ }^{43}$ Hofmeister 2000b, 41.

${ }^{44}$ Alternatively, an Iceland document from 1526 states that two tons should contain 120 fishes. One Hamburg ton weighs ninety pounds, and thus, one fish weighed 1.5 pounds (Baasch 1889, 65, 73). This suggests that Hamburg tons (bagenn) in 1526 may have been approximately half the size and less than half the weight of Lübeck tons in 1599. There are obviously some inaccuracies in the measuring system.

${ }^{45}$ For comparison, the present day European catch of cod is approximately one million metric tons per year $=7.2$ billion fish (Muus and Nielsen 1999, 123; FAO-values: http://de.wikipedia.org/wiki/Datei:Fisheries_capture_of_ Gadus_morhua.png, access date 01.12.2017).

${ }^{46}$ Küchelmann 2014, 22f; Bischop and Küchelmann 2018. 
${ }^{47}$ Heinrich 2006; Lepiksaar and Heinrich 1977; Schmölcke and Heinrich 2006.

${ }^{48}$ Heinrich 1987a.

${ }^{49}$ Ibid., 91ff.; http://www.fishbase.org/summary/Gadusmorhua.html, access date 01.12.2017.

${ }^{50}$ Barrett et al. 2004; Barrett et al. 2008.

${ }^{51}$ Isotope measurements from cod bones fragments of two sites in Lübeck (Julius-Leber-Straße, Fleischhauerstraße 64-72) were published by Orton et al. 2011.

${ }^{52}$ Barrett et al. 2008; Barrett et al. 2011.

${ }^{53}$ Orton, pers. com.

${ }^{54}$ Ólafsdóttir et al. 2014.

55 Thorlacius 1991.

${ }^{56}$ Ibid.

\section{References}

Printed sources (see also list of abbreviations)

Olaus Magnus. Die Wunder des Nordens, ed. and transl. by E. Balzamo and R. Kaiser. Frankfurt am Main: Eichborn, 2006.

\section{Secondary literature}

Baasch, E. 1889. Die Islandfahrt der Deutschen, namentlich der Hamburger vom 15. bis 17. Jahrhundert. Hamburg: Herold.

Bakker, J. K. 2014. About the Possibility to trace Jewish Urban Households by Means of an Ichtyo-archaeological Investigation. A Study on Archaeological Fish Remains from Post-Medieval Amsterdam and Medieval Cologne. Unpublished MSc thesis, Leiden University.

Barrett, J. H., Locker, A. and Roberts, C. M. 2004. The origins of intensive marine fishing in medieval Europe: the English evidence. Proceedings of the Royal Society of London B 271, 2417-2421.

Barrett, J. H., Johnstone, C., Harland, J., van Neer, W., Ervynck, A., Makowiecki, D., Heinrich, D., Hufthammer, A. K., Bødker-Enghoff, I., Amundsen, C., Christiansen, J. S., Jones, A. K. G., Locker, A., Hamilton-Dyer, S., Jonsson, L., Lougas, L., Roberts, C. M. and Richards, M. P. 2008. Detecting the medieval cod trade: a new method and first results. Journal of Archaeological Science 35, 850-861.

Barrett, J. H., Orton, D. C., Johnstone, C., Harland, J., van Neer, W., Ervynck, A., Roberts, C. M., Locker, A., Amundsen, C., Enghoff, I. B., Hamilton-Dyer, S., Heinrich, D., Hufthammer, A. K., Jones, A. K. G., Jonsson, L., Makowiecki, D., Pope, P., O'Connell, T. C., de Roo, T. and Richards, M. P. 2011. Interpreting the expansion of sea fishing in medieval Europe using stable isotope analysis of archaeological cod bones. Journal of Archaeological Science 38(7), 1516-1524.

Benecke, N. 1982. Zur frühmittelalterlichen Heringsfischerei im südlichen Ostseeraum - ein archäozoologischer Beitrag. Zeitschrift für Archäologie 16, 283-290.

Benecke, N. 1994. Archäozoologische Studien zur Entwicklung der Haustierhaltung in Mitteleuropa und Südskandinavien von den Anfängen bis zum ausgehenden Mittelalter. Schriften zur Ur- und Frühgeschichte 46. Berlin: Akademie Verlag.

Benecke, N. 1999. The project 'The Holocene History of the
European Vertebrate Fauna', in N. Benecke (ed.), The Holocene History of the European Vertebrate Fauna, 151-161. Archäologie in Eurasien 6. Rahden: Marie Leidorf.

Benecke, N., von den Driesch, A. and Heinrich, D. 2016. Holozängeschichte der Tierwelt Europas. Online database http://datenportal.ianus-fdz.de/pages/ collectionView.jsp?dipId $=1650048$

Berke, H. 1997. Haustiere, Handwerker und Händler. Vorläufige archäozoologische Ergebnisse der Ausgrabungen am Heumarkt in Köln. Kölner Jahrbuch 30, 405-413.

Berke, H. 2012. Koschere Küche - Tierknochen aus der Kloake unter der Synagoge, in S. Schütte and M. Gechter (eds), Von der Ausgrabung zum Museum Kölner Archäologie zwischen Rathaus und Praetorium. Ergebnisse und Materialien 2006-2012, 152-159, 327-330. Köln: Stadt Köln.

Bischop, D. and Küchelmann, H. C. 2018. Von der Küche in den Graben - Bremens Stadtgraben und die Essgewohnheiten seiner Anwohner an der Wende zur Frühen Neuzeit, in W. Melzer (ed.), Soester Beiträge zur Archäologie 15, 137-153. Soest: Mocker \& Jahn.

Bruns, F. 1900. Die Lübecker Bergenfahrer und ihre Chronistik. Berlin: Pass und Garleb.

Bruns, F. 1953. Das Frachtherrenbuch der Lübecker Bergenfahrer. Bergen: John Griegs.

Casteel, R. W. 1976. Fish Remains in Archaeology. London: Academic Press.

Christiansen, J. 1998. Focke-Museum. Ein Führer durch die Sammlungen. Bremen: Focke-Museum.

Clason, A. T. and Prummel, W. 1977. Collecting, sieving and archaeozoological research. Journal of Archaeological Science 4, 171-175.

Davis, S. J. M. 1995. The Archaeology of Animals. London: B. T. Batsford.

von den Driesch, A. 1982. Fischreste aus der slawischdeutschen Fürstenburg auf dem Weinberg in Hitzacker (Elbe). Neue Ausgrabungen und Forschungen in Niedersachsen 15, 395-423.

Galik, A. and Küchelmann, H. C. 2008. Fischreste aus der mittelalterlichen Bremer Altstadt, Bremer Archäologische Blätter, Neue Folge 7, 215-231.

Gardiner, M. and Mehler, N. 2007. English and Hanseatic trading and fishing in medieval Iceland: report on initial fieldwork. Germania 85, 385-427.

Grimm, J. M. and Schneider, M. 2005. Keine Lust zum Geschirrspülen? Auswertung der spätmittelalterlichen Tierknochen und der botanischen Reste aus der Remternische des Katharinenklosters in Stralsund, in I. Ericsson and R. Atzbach (eds), Depotfunde aus Gebäuden Zentraleuropas, 173-180. Berlin: scripvaz.

Hammel-Kiesow, R. 2005. Quellen zur Lübecker Bergenfahrt im 17. Jahrhundert aus den Beständen des Archivs der Bergenfahrerkompanie zu Lübeck und des Hansischen Kontors zu Bergen in Norwegen, in A. Graßmann (ed.), Das Hansische Kontor zu Bergen und die Lübecker Bergenfahrer, 116-139. Lübeck: Archiv der Hansestadt Lübeck.

Heinrich, D. 1985. Die Fischreste aus der frühgeschichtlichen Marschensiedlung beim Elisenhof in Eiderstedt. Kiel: Archäologisch-Zoologische Arbeitsgruppe. 
Heinrich, D. 1986. Fang und Konsum von Kabeljau im Mittelalter. Offa 43, 87-93.

Heinrich, D. 1987a. Untersuchungen an mittelalterlichen Fischresten aus Schleswig - Ausgrabung Schild 1971-1975. Neumünster: Wachholtz.

Heinrich, D. 1987b. Fish remains from Göttingen/ Niedersachsen, excavation Johannisstr. 21-25, 12701345 A.D., Ichthyo-Osteo-Archaeology News 4, 10-12.

Heinrich, D. 1992. Fischknochen aus mittelalterlichen Siedlungsabfällen in Duisburg. Duisburger Forschungen 38, 295-305.

Heinrich, D. 1994. Die Fischreste aus der frühgeschichtlichen Wurt Elisenhof. Studien zur Küstenarchäologie Schleswig-Holsteins 6, 214-271. Frankfurt a. Main: Lang.

Heinrich, D. 1995. Untersuchungen an Fischresten aus Kloaken des 17. Jahrhunderts in Höxter sowie Bemerkungen zu den dort geborgenen Knochen von Froschlurchen. Ausgrabungen und Funde in WestfalenLippe 9(B), 381-398.

Heinrich, D. 1999a. Some methodological considerations with regard to analyses of faunal history with special reference to fish remains, in N. Benecke (ed.), The Holocene History of the European Vertebrate FaunaModern Aspects of Research. Archäologie in Eurasien 6, 163-170. Rahden: Marie Leidorf.

Heinrich, D. 1999b. Die Faunenreste von Schleswig und anderer mittelalterlicher Siedlungsplätze SchleswigHolsteins. Eine vergleichende Betrachtung. Offa 53, 327-370.

Heinrich, D. 2006. Die Fischreste aus dem Hafen von Haithabu - Handaufgelesene Funde. Berichte über die Ausgrabungen in Haithabu 35, 157-193.

Heinrich, D. 2008. Fischkonsum in Luthers Elternhaus als Spiegel für Fischerei und Fischhandel in der frühen Neuzeit, in H. Meller, S. Rhein and H.-G. Stephan (eds), Luthers Lebenswelten. Tagungen des Landesmuseums für Vorgeschichte Halle 1, 337-345. Halle: Landesamt.

Heinrich, D. 2012. The animal remains from the wreck of the cog from Wismar-Wendorf (fifteenth century AD), in D. C. M. Raemaekers, K. Esser, R. C. G. M. Lauwerier and J- T. Zeiler (eds), A Bouquet of Archaeozoological Studies. Essays in honour of Wietske Prummel. Groningen Archaeological Studies 21, 164-169. Groningen: Barkhuis.

Heinrich, D., Reichstein, H. and Schietzel, K. 1991. 25 Jahre Archäologisch-Zoologische Arbeitsgruppe SchleswigKiel. Offa 48, 9-39.

Heinrich, D., Schulz, F. and Wiethold, J. 1994. Archäobotanische und archäozoologische Funde aus den mittelalterlichen Wehrgräben von Kiel. Archäologische Nachrichten aus Schleswig-Holstein 4/5, 70-102.

Herre, W. 1950a. Haustiere im mittelalterlichen Hamburg. Untersuchungen über die Tierknochenfunde in der Kleinen Bäckerstraße. Hammaburg 4(1), 7-19.

Herre, W. 1950b. Zur Abstammung und Entwicklung der Haustiere. III. Die Haustierreste mittelalterlicher Siedlungen der Hamburger Altstadt. Der Zoologische Garten, Neue Folge 17, 103-121.

Hoffmeister, U. 1994. Untersuchungen an Tierknochen aus einer frühneuzeitlichen Kloake (Mitte 16. bis Anfang
17. Jh.) des Heilig-Geist-Hospitals in Höxter/Weser. Unpublished thesis, Kiel University.

Hofmeister, A. E. 2000a. Das Schuldbuch eines Bremer Islandkaufmanns, in A. E. Hofmeister and A. Löhr (eds), Kirche - Kaufmann - Kabeljau: 1000 Jahre Bremer Islandfahrt. Kleine Schriften des Staatsarchivs Bremen 30, 47-54. Bremen: Staatsarchiv.

Hofmeister, A. E. 2000b. Hansische Kaufleute auf Island im 15. und 16. Jahrhundert, in A. E. Hofmeister and A. Löhr (eds), Kirche - Kaufmann - Kabeljau: 1000 Jahre Bremer Islandfahrt. Kleine Schriften des Staatsarchivs Bremen 30, 33-46. Bremen: Staatsarchiv.

Hofmeister, A. E. 2001. Das Schuldbuch eines Bremer Islandfahrers aus dem Jahre 1558. Bremisches Jahrbuch $80,20-50$.

Huczko, S. 1986. Die Tierknochenfunde vom Domplatz in Osnabrück (12.-17. Jahrhundert). Schriften aus der Archäologisch-Zoologischen Arbeitsgruppe SchleswigKiel 10. Kiel: Archäologisch-Zoologische Arbeitsgruppe.

Johansson, F. and Heinrich, D. 1979. Einige Angaben zu Tierknochenfunden aus der Altstadt von Kiel. Offa 36, 152-162.

Küchelmann, H. C. 2003. Fischreste aus der Bremer Altstadt - Fundstelle 127 - 'Astoria' - Grabung 2003. Report Landesarchäologie Bremen.

Küchelmann, H. C. 2004. 'Quappen zu kochen' - Fischreste aus der Grabung 'Melchers' in Bremen (Fundstelle 209 Altstadt 2003). Report Landesarchäologie Bremen.

Küchelmann, H. C. 2014a. Mit Knochen gepflastert - Tierknochenfunde vom Bremer Marktplatz (Fundstelle 201-Altstadt 2002). Schriften des Naturwissenschaftlichen Vereins für Schleswig-Holstein 73, 23-64.

Küchelmann, H. C. 2014b. Frühneuzeitliche Tierknochen aus dem Bremer Stadtgraben, Grabung 253-Altstadt 2011 Am Wall. Report Landesarchäologie Bremen.

Küchelmann, H. C. in preparation. Tierknochenfunde von der frühneuzeitlichen Adamspforte in Bremen (Fundstelle 220-Altstadt 2004-2006). Report Landesarchäologie Bremen.

Küchelmann, H. C. and Nolde, N. in preparation. Tierknochenfunde aus der mittelalterlichen Langenstraße 31-35 in Bremen (Fundstelle 218-Altstadt 2004). Report Landesarchäologie Bremen.

Lepiksaar, J. and Heinrich, D. 1977. Untersuchungen an Fischresten aus der frühmittelalterlichen Siedlung Haithabu. Berichte über die Ausgrabungen in Haithabu 10. Neumünster: Wachholtz.

Libois, R. M. and Hallet-Libois, C. 1988. Éléments pour l'Identification des Restes Craniens des Poissons dulcaquicoles de Belgique et du Nord de la France. 2 - Cypriniformes. Fiches d'Ostéologie Animale pour l'Archéologie Série A, Poissons 4. Juan-les-Pins: APDCA.

Lorenzen-Schmidt, K.-J. 2013. Fischkonsum in einem Hamburger Großhaushalt 1504-1506. Rundbrief des Arbeitskreises für Wirtschafts- und Sozialgeschichte Schleswig-Holsteins 111, 50-51.

Lyman, R. L. 1994. Vertebrate Taphonomy. Cambridge: University Press.

Mehner, T. 1990. Zur Bestimmung der Beutefischarten aus Fragmenten der Wirbelsäule bei der Nahrungsanalyse 
(Ostheichthyes, Teleostei). Zoologischer Anzeiger 225(3-4), 210-222.

Morales, A. and Rosenlund, K. 1979. Fish Bone Measurements - An Attempt to Standardize the Measuring of Fish Bones from Archaeological Sites. Copenhagen: Steenstrupia.

Müller, A. H. 1992. Lehrbuch der Paläozoologie I: Allgemeine Grundlagen. Stuttgart: Gustav Fischer, fifth edition.

Muus, B. J. and Nielsen, J. G. 1999. Die Meeresfische Europas in Nordsee, Ostsee und Atlantik. Stuttgart: Kosmos-Franckh.

Niedenführ, A. 2002. Untersuchung von Kleintierresten der Fundstelle mit der Bezeichnung '127 Altstadt Bf 36' auf Säugetierknochen. Report Landesarchäologie Bremen.

Nobis, G. and Ninov, L. 1992. Zur Haustierwelt des Mittelalters nach Studien an Tierresten aus der Altstadt von Duisburg. Duisburger Forschungen 38, 237-294.

Nolde, N. 2013. Die Tierknochenfunde aus der Grabung 'Radio Bremen'. Fundstelle Bremen 217-Altstadt. Report Landesarchäologie Bremen.

O'Connor, T. P. 2000. The Archaeology of Animal Bones. Stroud: Sutton Publishing.

Ólafsdottir, G. Á., Westfall, K. M., Edvardsson, R. and Pálsson, S. 2014. Historical DNA reveals the demographic history of Atlantic cod (Gadus morhua) in medieval and early modern Iceland. Proceedings of the Royal Society of London B 281. http://dx.doi.org/10.1098/ rspb.2013.2976

Orton, D. C., Makowiecki, D., de Roo, T., Johnstone, C., Harland, J., Jonsson, L., Heinrich, D., Bødker-Enghoff, I., Lougas, L., van Neer, W., Ervynck, A., Hufthammer, A. K., Amundsen, C., Jones, A. K. G., Locker, A., Hamilton-Dyer, S., Pope, P., Mackenzie, B. R., Richards, M. P., O'Connell, T. C. and Barrett, J. H. 2011. Stable isotope evidence for late medieval (14th-15th c) origins of the eastern Baltic cod (Gadus morhua) fishery. PlosONE 6(11): e27568. https://doi.org/10.1371/journal. pone.0027568

Paul, A. 1977. Knochenfunde aus dem mittelalterlich neuzeitlichen Lübeck (Grabung Hundestraße 9-11). Unpublished manuscript.

Paul, A. 1980. Untersuchungen an Tierknochen aus dem mittelalterlichen Lübeck (Grabung Königstraße 59-63). Lübecker Schriften zur Archäologie und Kulturgeschichte 2, 7-104.

Perdikaris, S. 1997. The transition to a commercial economy: Lofoten fishing in the Middle Ages, a preliminary report. Anthropozoologica 25/26, 505-510.

Perdikaris, S., Krigorskaya, Y., McGovern, T. and Lahtiperä, P. 2004. Fishbone 1.1 CD - Identification manual for Gadid fish in the North Atlantic, CD. New York: North Atlantic Biocultural Organisation.

Pieper, H. and Reichstein, H. 1995. Untersuchungen an Skelettresten von Vögeln aus dem mittelalterlichen Schleswig. Ausgrabungen in Schleswig, Berichte und Studien 11, 9-113.

Prilloff, R.-J. 1999. Tierische Rohstoffe für den städtischen Markt in Halberstadt. Ergebnisse einer archäozoologischen Studie an Tierknochen der Frühen Neuzeit aus dem Keller des Hauses Holzmarkt 2. Nordharzer Jahrbuch 20/21, 203-289.
Prilloff, R.-J. 2002. Archäozoologische Beiträge zur Geschichte der Stadt Erfurt. Erfurter Beiträge 3, 71-102.

Prilloff, R.-J. 2005. Herrschaftliches Speisen und Jagen, in B. Kunz (ed.), Schaufenster der Archäologie. Neues aus der archäologischen Forschung in Magdeburg, 81-84. Magdeburg: Landesamt für Denkmalpflege.

Prilloff, R.-J. 2011. Kaninchen und Grünschenkel frühneuzeitliche Tierreste aus Magdeburg. Archäologie in Sachsen-Anhalt 5, 268-284.

Prummel, W., Esser, K. and Zeiler, J. T. 2013. The animals on the terp Wijnaldum-Tjitsma (The Netherlands) - reflections on the landscape, economy and social status. Siedlungs- und Küstenforschung im südlichen Nordseegebiet 36, 87-98.

Pudek, N. 1980. Untersuchungen an Tierknochen des 13.-20. Jahrhunderts aus dem Heiligen-Geist-Hospital in Lübeck. Lübecker Schriften zur Archäologie und Kulturgeschichte 2, 107-201.

Pyrozok, A. and Reichstein, H. 1991. Tierknochenfunde aus hochmittelalterlichen Siedlungsablagerungen in Lübeck (Grabung Dr.-Julius-Leber-Straße 58). Lübecker Schriften zur Archäologie und Kulturgeschichte 21, 183-202.

Quade, V. 1984. Die Tierknochen aus der Kloake der Lübecker Fronerei (15.-17. Jahrhundert). Lübecker Schriften zur Archäologie und Kulturgeschichte 8, 105-167.

Rackham, J. 1994. Animal Bones, Interpreting the Past. London: British Museum.

Radu, V. 2005. Atlas for the Identification of Bony Fish Bones from Archaeological Sites. Studii de Preistorie Supplementum 1. Bucharest: Editura Contrast.

Reichstein, H. 1992. Vogelknochen aus mittelalterlichen Siedlungsabfällen in Duisburg. Duisburger Forschungen 38, 306-315.

Reichstein, H. 1993. Tierknochen aus acht Jahrhunderten aus der Hansestadt Lübeck, in M. Gläser (ed.), Archäologie des Mittelalters und Bauforschung im Hanseraum. Schriften des Kulturhistorischen Museums in Rostock 1, 511-515. Rostock: Konrad Reich.

Reichstein, H. 1995a. Ein Tierknochen-Fundkomplex aus einer Kloake in der Göttinger Altstadt (Anfang 15. Jahrhundert). Nachrichten aus Niedersachsens Urgeschichte 64(1), 93-129.

Reichstein, H. 1995b. Tierknochen aus renaissancezeitlichen Kloakenschächten der 1. Hälfte des 17. Jahrhunderts in Höxter a. d. Weser. Ausgrabungen und Funde in Westfalen-Lippe 9(B), 327-380.

Reichstein, H. 1999. Zur Ernährung der Bewohner von Hameln/Weser im späten Mittelalter und dem ausgehenden 18. Jh. im Spiegel von Tierknochenfunden, in C. Becker, H. Manhart, J. Peters and J. Schibler (eds), Historia animalium ex ossibus - Beiträge zur Paläoanatomie, Archäologie, Ägyptologie, Ethnologie und Geschichte der Tiermedizin, 388-399. Rahden: Marie Leidorf.

Rheingans, A. and Reichstein, H. 1991. Untersuchungen an Tierknochen aus mittelalterlichen bis neuzeitlichen Siedlungsabfällen in Lübeck (Ausgrabung Alfstraße 36/38). Lübecker Schriften zur Archäologie und Kulturgeschichte 21, 143-181. 
Rohlf, K. 1978. Untersuchungen an Tierknochen aus mittelalterlichen bis neuzeitlichen Siedlungsschichten in Lübeck (Grabung Hundestraße 13-17). Unpublished thesis, Kiel University.

Rojo, A. 1986. Live length and weight of cod (Gadus morhua) estimated from various skeletal elements. North American Archaeologist 7(4), 329-351.

Schmölcke, U. and Heinrich, D. 2006. Die Tierknochen aus dem Hafen von Haithabu - Schlämmfunde. Berichte über die Ausgrabungen in Haithabu 35, 195-239.

Schulze-Rehm, C. 1995. Ergebnisse der archäozoologischen Bearbeitung der Tierknochenfunde aus der Kloake 4 von Fundstelle 17:2 'Auf dem Wüstenort' in Lüneburg. Archäologie und Bauforschung in Lüneburg 1, 167-174.

Skivenes, A. 2005. 'So long - and thanks for all the fish'
- The German Wharf fish trade as seen in Bergen archival sources, in A. Graßmann (ed.), Das Hansische Kontor zu Bergen und die Lübecker Bergenfahrer. Veröffentlichungen zur Geschichte der Hansestadt Lübeck Reihe B 41, 94-109. Lübeck: Archiv der Hansestadt Lübeck.

Thorlacius, B. 1991. A Brief History of the Icelandic Coat of arms. http://eng.forsaetisraduneyti.is/state-symbols/ icelandic-coat-of-arms/history.

Watt, J., Pierce, G. J. and Boyle, P. R. 1997. Guide to the Identification of North Sea Fish Using Premaxillae and Vertebrae. International Council for the Exploration of the Sea Cooperative Research Report 220.

Copenhagen: International Council for the Exploration of the Sea. 